\title{
O Corpo (Fantástico) e o Espaço
}

A relação que o corpo (fantástico) estabelece com o espaço permite diferentes interpretações e discursos. Por um lado, a presença do corpo nos diferentes espaços explora temas como o real a e imaginação, o natural e o sobrenatural. Por outro, esta é também uma forma de questionar identidades e representações ou os valores culturais do passado e do presente. As mais recentes criações, quer a nível literário, quer a nível cinematográfico e televisivo, apostam em viagens fantásticas que subvertem a realidade tal qual a conhecemos e exploram a diferença, o Outro e, acima de tudo, sublinham o modo como o espaço não pode ser dissociado da experiência corporal daquele que o percepciona (GARCIA, 2015, p. 53).

Este número temático da Redisco - Revista Electrónica dos Estudos do Discurso e do Corpo procura, assim, leituras variadas sobre corpos e o espaço, nas suas muitas vertentes e expressões: Literatura, Banda Desenhada, Cinema, Fotografia, Televisão ou Dança, mas também outras artes visuais e criativas. Foi dado especial destaque aos ensaios que investigaram esta relação entre espaço, corpo e fantástico e aquilo que foge ao que é imediatamente reconhecível, que nos é estranho e próximo ao mesmo tempo. Assim, este número da Redisco concentra a sua atenção nesta temática e é composto por nove artigos de autores de diferente países: Algéria, Brasil, E.U.A., Inglaterra, Israel e Portugal, naquela que pode ser entendida como uma colaboração internacional - e cada vez mais necessária - de estudiosos que se interessem por este tema, especialmente dada a diversidade de textos encontrados neste número. Deste modo, a organização do presente volume estrutura-se em quatro momentos essenciais.

O primeiro, ocupando-se do fantástico e o espaço na literatura, começa com o texto de Marisa Martins Gama-Khalil e Jamille da Silva Santos, uma colaboração que 
explora os insólitos corpos fantásticos no conto "Miss Algrave" (1984), de Clarice Lispector, focando a sua atenção no modo como a ficção brasileira lida com a ficção científica e, em particular, com a imagem do alienígena.

Em seguida, e passando pela literatura Portuguesa, Igor Furão analisa o romance de José Luís Peixoto Uma Casa na Escuridão (2002), considerando a obra como uma importante reflexão sobre o fantástico, a memória e a identidade portuguesa, em particular a partir do momento do ataque do 11 de Setembro de 2001.

O terceiro texto, pela mão de Nassima Kaid, desvia a sua atenção para um conjunto de romances do universo da cultura popular: a saga Twilight, de Stephenie Meyer. Considerando a forma como a obra foge à tradição, a autora estuda as representações dos corpos fantásticos na obra, nomeadamente vampiros e lobisomens.

Ainda dentro deste primeiro momento, mas já a apontar para a segunda parte deste número, surge o texto de Elana Gomel, que olha para a cidade fantástica em diversas obras, e com três diferentes representações: a cidade obscura, a cidade-máquina e a cidade enquanto organismo/corpo. Os exemplos dados pela autora, que oscilam entre a literatura e o cinema, servem para ilustrar a importância deste espaço na ficção fantástica contemporânea.

É também no cinema e outras artes que esta segunda parte do número especial da Redisco se foca. O texto de José Duarte, que abre esta segunda secção, dá destaque ao cinema, em particular à relação do cinema com o espaço urbano imaginado e produzido pela Banda Desenhada, como é o caso de Batman. Assim, o autor procura olhar para as diferentes representações de Gotham e Batman ao longo do tempo, especialmente no cinema e especificamente na trilogia realizada por Christopher Nolan ocupando-se de examinar a relação entre os corpos fantásticos e o espaço.

Já o texto de Cindy Hendershot dá também destaque ao cinema, em particular a American Mary (2012, Jen e Sylvia Soska), Maniac (2012, Franck Khaulfon) e The Invitation (2015, Karyn Kusama), três filmes de horror contemporâneos com temáticas similares: o corpo e a sua transformação. A análise proposta é feita a partir da teoria crítica Freudiana que, uma vez aplicada a estes filmes, prova ainda ser essencial para os compreender. 
Da mesma forma, Elisabete Lopes estuda o filme American Mary (2012), de Jen e Sylvia Soska, sendo que o seu ensaio dedica toda a atenção a este filme, explorando o corpo enquanto foco de horror. A autora procura, assim, compreender, por um lado, o corpo como um repositório mitológico e, por outro, as criações corporais apresentadas no filme, o que fazem desta obra um interessante exemplo para explorar o horror e o corpo, e o modo como este é apresentado num espaço violento.

O terceiro momento é estruturado por dois ensaios que focam a dimensão corporal no contexto da dança e na fotografia. Roselene de Fátima Coito empreende uma cuidada análise da coreografia do batuque, uma dança africana, observando na sua manifestação coreográfica o elemento fantástico, e colocando-o em perspectiva com a teoria de Michel Foucault.

Já o texto de Ivânia Neves e Ana Shirley Cardoso olha para as fotografias de Cláudia Andujar e para os seus múltiplos significados, em particular ao fazer uma análise das diferentes temporalidades apresentadas em "Sonhos Yanomami". Esta é uma série que inscreve o corpo Yanomami nos média nacionais e internacionais, onde são estabelecidos jogos entre ficção e realidade.

A última parte desta edição especial vai para lá dos nove ensaios, pois o número conta também com uma entrevista a Stephen Hunt, reputado escritor de Inglaterra - mas que vive em Espanha - de obras fantásticas e de Ficção Científica. A entrevista realizada por José Duarte e Ana Rita Martins pretende colocar em evidência a relação que o escritor tem com as suas criações, mas também alguns dos temas que explora: a tecnologia, a religião, para além dos espaços alternativos e os corpos que os habitam. Esta pareceu-nos ser uma excelente adição para este número, uma vez que apresenta uma outra leitura e complementa as temáticas exploradas na Redisco.

Afigura-se necessário ainda uma nota à capa. Esta foi elaborada pelo artista/ilustrador Luís Filipe Lopes (FIL - www.filbd.blogspot.pt), que gentilmente cedeu o seu trabalho para figurar como capa desta edição. Também ele procurou explorar a relação do corpo (fantástico) com o espaço e, assim, colaborar visualmente para que este número funcione como um todo. 
Finalmente, é de sublinhar a importância desta colaboração entre investigadores de diferentes países, possível em grande medida pela abertura da revista que, dedicando-se aos estudos do corpo e do discurso, possibilitou a existência de um número que olha para os corpos - fantásticos, de dimensões e significados diferentes - e o espaço que estes ocupam.

Os organizadores,

José Duarte

Ana Rita Martins

Nilton Milanez. 


\section{The (Fantastic) Body and Space*}

The relation between the (fantastic) body and space allows for a variety of interpretations and discourses. On the one hand, the presence of the body in different spaces explores topics such as the real and the imaginary or the natural and the supernatural. On the other hand, this also represents a form of questioning identities and representations or past and present cultural values. Most recent trends - be it on a literary or on a cinematic and televisual level - rely on fantastic voyages that subvert reality as we know it by exploring alterity, the Other, and, above all, by highlighting the way in which space cannot be separated from the corporeal experience of the one perceiving it (GARCIA, 2015, p. 53).

This thematic issue of Redisco - Revista Electrónica dos Estudos do Discurso e do Corpo hence looks at a variety of readings about bodies and space in all their numerous dimensions and expressions: Literature, Comics, Cinema, Photography, Television, or Dance, as well as other visual and creative arts.

Special emphasis has been given to essays that investigate the relation between space, the body, the fantastic, and that which breaks away from the immediately recognizable or causes a sense of strangeness, and yet is familiar to us. Thus, this issue of Redisco consists of nine essays written by authors from different countries that focus on this topic: Algeria, Brazil, U.S.A., England, Israel, and Portugal, turning this issue into an - increasingly vital - international collaboration of scholars interested in the subject matter at hand, especially taking into account the diversity of texts found in this issue. As a result, the present issue is structured into four essential parts.

The first part addresses the fantastic and space in literature, opening with a text by Marisa Martins Gama-Khalil and Jamille da Silva Santos, a collaboration that explores 
uncanny fantastic bodies in Clarice Lispector's short story "Miss Algrave" (1984) by bringing into focus the way in which Brazilian fiction deals with science fiction and, in particular, with the image of the alien.

Next, touching upon Portuguese literature, Igor Furão analyzes José Luís Peixoto's novel Uma Casa na Escuridão (2002), approaching the work as an important reflection on the fantastic, memory, and Portuguese identity by placing it particularly in relation to the aftermath of the attacks of September 11, 2001.

The third text, written by Nassima Kaid, draws attention to a novel series taken from the realm of popular culture: Twilight (2006-2012), by Stephenie Meyer. Bearing in mind the way in which the series rejects tradition, the author examines the representations of the fantastic bodies of vampires and werewolves in this work.

Still in this first section, but already aiming at the second part of this issue, is Elana Gomel's text that looks at the fantastic city in various works, or rather at three different representations: the obscure city, the city as a machine, and the city as organism/body. The examples given by the author alternate between literature and cinema and serve to demonstrate the importance of this space in contemporary fantastic fiction.

It is precisely cinema and other arts that the second part of this special issue of Redisco addresses. The text by José Duarte, which introduces this second section, brings into focus the cinematic by highlighting the relation between cinema and the urban space imagined or produced by comics, as is the case in Batman. Hence, the author seeks to investigate the different cinematic representations of Gotham and Batman over time, specifically in the trilogy directed by Christopher Nolan, through his analysis of the relation between fantastic bodies and space.

Cindy Hendershot's text also seeks to put special emphasis on cinema by addressing three contemporary horror films, American Mary (2012, Jen and Sylvia Soska), Maniac (2012, Franck Khaulfon), and The Invitation (2015, Karyn Kusama), all of which approach similar themes: the transforming body. The proposed analytical approach is based on Freudian theory that, once applied, proves to be essential to the understanding of these films. 
Likewise, Elisabete Lopes studies the film American Mary (2012) by Jen and Sylvia Soska, making the film the main focus of her essay by exploring the body as a source of horror. The author thus seeks to understand the body as a mythological vessel, besides investigating the corporeal creations presented in the film that turn this work into an interesting example for the exploration of horror and the body and the ways in which the body is presented in a violent space.

The third section consists of two essays that focus on corporeality in the context of dance and photography. Roselene de Fátima Coito embarks on a thorough analysis of the African batuque dance, detecting in its choreographic manifestation an element of the fantastic, which in turn is put into perspective with the help of Michel Foucault's theory.

The text by Ivânia Neves and Ana Shirley Cardoso takes a look at photographs by Cláudia Andujar and their multiple meanings, more specifically by analyzing the different temporalities presented in "Sonhos Yanomami" ("Yanomami Dreams"). This series inserts the Yanomami body into national and international media, where games between fiction and reality are played.

The last part of this special issue goes beyond the nine essays, seeing that it also includes an interview with renowned English writer Stephen Hunt, currently living in Spain, about works on the fantastic and science fiction. Held by José Duarte and Ana Rita Martins, the interview aims to highlight the writer's relation to his works and to certain topics he explores: technology, religion, and the alternative spaces and bodies they inhabit. This felt like an excellent addition to this issue, considering that it presents a different reading and complements the themes explored in Redisco.

We would also like to add a quick note regarding the cover: it was designed by artist/illustrator Luís Filipe Lopes (FIL - www.filbd.blogspot.pt), who kindly contributed his work to grace this issue. He too has sought to explore the relation between the (fantastic) body and space and, as a result, has given this issue coherence and unity through his visual collaboration.

Finally, we need to stress the importance of collaborating with researchers from different countries, an endeavor largely made possible by the openness of this journal to 
studies related to the body and discourse. This enabled the existence of an issue engaging with (fantastic) bodies -with different dimensions and meanings - and the space that they inhabit.

The organizers

José Duarte

Ana Rita Martins

Nilton Milanez.

* Translated by David Klein Martins 